\title{
Distribution of Angiostrongylus vasorum and its gastropod intermediate hosts along the rural-urban gradient in two cities in the United Kingdom, using real time PCR
}

Nor Azlina A. Aziz ${ }^{1,2^{*}}$, Elizabeth Daly ${ }^{1}$, Simon Allen ${ }^{1,3}$, Ben Rowson ${ }^{4}$, Carolyn Greig ${ }^{3}$, Dan Forman ${ }^{3}$ and Eric R. Morgan ${ }^{1}$

\begin{abstract}
Background: Angiostrongylus vasorum is a highly pathogenic metastrongylid nematode affecting dogs, which uses gastropod molluscs as intermediate hosts. The geographical distribution of the parasite appears to be heterogeneous or patchy and understanding of the factors underlying this heterogeneity is limited. In this study, we compared the species of gastropod present and the prevalence of $A$. vasorum along a rural-urban gradient in two cities in the south-west United Kingdom.

Methods: The study was conducted in Swansea in south Wales (a known endemic hotspot for A. vasorum) and Bristol in south-west England (where reported cases are rare). In each location, slugs were sampled from nine sites across three broad habitat types (urban, suburban and rural). A total of 180 slugs were collected in Swansea in autumn 2012 and 338 in Bristol in summer 2014. A 10 mg sample of foot tissue was tested for the presence of $A$. vasorum by amplification of the second internal transcribed spacer (ITS-2) using a previously validated real-time PCR assay.

Results: There was a significant difference in the prevalence of $A$. vasorum in slugs between cities: $29.4 \%$ in Swansea and $0.3 \%$ in Bristol. In Swansea, prevalence was higher in suburban than in rural and urban areas. Comparing the sampled slug fauna, Arion rufus was found in greater numbers in Swansea than Bristol, and was commonly infected (prevalence $41 \%$ ). This, alongside the timing of slug collections in summer rather than autumn, could explain low infection prevalence in the Bristol sample. In the absence of Ar. rufus as a preferred host for $A$. vasorum, Ar. flagellus and Limacus maculatus appear to act as versatile hosts that are present in suburban and urban areas in Swansea (prevalence in Ar. flagellus 33 \%; in L. maculatus 44 \%) and in Bristol (prevalence in Ar. flagellus $0.9 \%$ ). These slug species might provide $A$. vasorum with an alternative vehicle to reach the final host, when the main host Ar. rufus is scarce or absent.

Conclusion: We conclude that the composition of the slug fauna varies spatially, and that this could help explain patchiness in the prevalence of A. vasorum. A suburban peak was found in the prevalence of infection in intermediate hosts, perhaps explained by a higher density of competent intermediate and/or definitive hosts.
\end{abstract}

Keywords: Angiostrongylosis, Suburban, Gastropods, Epidemiology, Distribution

\footnotetext{
* Correspondence: azlinaaziz@unisza.edu.my

'University of Bristol, Veterinary Parasitology \& Ecology Group, School of

Biological Sciences, Bristol Life Sciences Building, 24, Tyndall Avenue, Bristol BS8 1TQ, UK

${ }^{2}$ School of Animal Sciences, Faculty of Bioresources and Food Industry,

Universiti Sultan Zainal Abidin, Kampus Tembila, 22200 Terengganu, Malaysia

Full list of author information is available at the end of the article
} 


\section{Background}

Angiostrongylus vasorum is an emerging parasite in dogs, with frequent new reports throughout Europe and beyond $[1,2]$. Within several endemic Europe countries, its distribution appears to be expanding, but in a highly heterogeneous or patchy manner. In the United Kingdom (UK), A. vasorum was first reported in Cornwall in southwest England in the 1970s [3, 4], later in Wales and southeast England [5-7], and recently in central and northern England and Scotland [8-12]. National questionnaire surveys of veterinary practices confirmed both northward spread and persistent heterogeneity in disease incidence in dogs [13]. Better understanding of the factors underlying this patchy distribution is needed to guide risk assessments by veterinary clinicians and other stakeholders, in order to prevent and control the severe disease that can ensue from infection [14], as well as to build on currently sparse fundamental understanding of the epidemiology of nematode parasites in gastropod intermediate hosts $[15,16]$.

Angiostrongylus vasorum has an indirect life-cycle with canids such as domestic dogs (Canis lupus familiaris) and red foxes (Vulpes vulpes) as the definitive host, terrestrial gastropod molluscs (slug or snail) acting as intermediate hosts, and frogs acting as paratenic or intermediate hosts [17]. Heterogeneity in parasite abundance and disease risk to definitive hosts could arise from variable environmental influences on mollusc populations and infection rates. Using a recently developed real time polymerase chain reaction (PCR) assay [18], surveys of prevalence in slugs are feasible. Previous studies assessing the presence of $A$. vasorum in slugs and snails have reported variable prevalence. In Denmark, $29 \%$ of molluscs sampled contained larvae and prevalence varied by locality [19]. The species found to be infected in this study were Arion lusitanicus, Ar. ater, Ar. aterrufus and Limax maximus. A survey in south Wales (UK) reported $43 \%$ prevalence using PCR, with Ar. ater aggregate, Ar. hortensis aggregate and Deroceras sp. positive [18]. In London (UK), prevalence of larval recovery from slugs was $1.6 \%$, with a broad host range including two species previously not recorded as acting as intermediate hosts for A. vasorum: Ar.distinctus and Tandonia sowerbyi [20]. In a PCR survey of slugs in west Scotland, an area newly colonised by $A$. vasorum, the slug fauna and positive slugs were dominated by large Arion species [11], with overall prevalence of $7 \%$.

The aims of the present study were to determine the prevalence of infection in slugs in contrasting areas within a region endemic for $A$. vasorum, and to determine whether differences in slug species composition could explain differences in overall prevalence. This information is needed to better understand the role of slugs as intermediate hosts for $A$. vasorum, the factors underlying local risks of transmission, and the most important slug species involved as sources of infection for dogs.

\section{Ethical approval}

Ethical review details are not provided since no formal ethical approval was necessary: the work involves neither work on vertebrates nor human participants or personal data.

\section{Methods}

\section{Study area}

Slugs were collected from parks within a $20 \mathrm{~km}$ radius of the centres of two nearby cities, Swansea in south Wales (a known endemic hotspot for A. vasorum) (Fig. 1) and Bristol in south-west England (Fig. 2). In Swansea, 180 slugs were collected from October to November 2012, from publicly accessible areas along a rural-urban transect (Table 1). In Bristol, 338 slugs were collected from public parks in July and August 2014 (Table 2). In each location, nine sites were sampled across three broad habitat types (urban, suburban and rural), which were categorised subjectively. Urban areas were close to the city centres, and either built-up (e.g. housing, or tarmacadam-based landscaping) or brown-field (i.e. unused and unmanaged previously built-up land). Suburban areas were composed of a mixture of housing with private gardens, and publicly accessible green space (i.e. public parks), from which slugs were sampled. Rural areas were publicly accessible amenity areas outside the city boundaries, comprising open green fields and woodland, with sampling undertaken from woodland-grassland and ecotones.

\section{Collection and processing of slugs}

Slugs were collected by actively searching the ground and surface vegetation, soon after dusk by torchlight. All slugs were stored together in labelled plastic boxes according to sampling site. In Swansea, immediate examination of slugs was not possible and so slugs were frozen at $-80{ }^{\circ} \mathrm{C}$ until used for DNA extraction. Slugs collected in Bristol were kept at $15{ }^{\circ} \mathrm{C}$ and processed within a few days of collection: boxes were lined with moistened tissue paper and supplemented with lettuce and carrot as a food source. Individual slugs were identified using Rowson et al. [21, 22] and were assigned either to genus or species level. Following identification, slugs were killed by decapitation, and $10 \mathrm{mg}$ of foot tissue used for DNA extraction and real time PCR assays. Very few snails were observed and none were collected.

\section{DNA extraction and real time PCR assays}

DNA was extracted using DNEasy Blood and Tissue Kit (Qiagen, Germany) according to the animal tissue extraction protocol, with final elution volume of $100 \mu \mathrm{l}$. A 


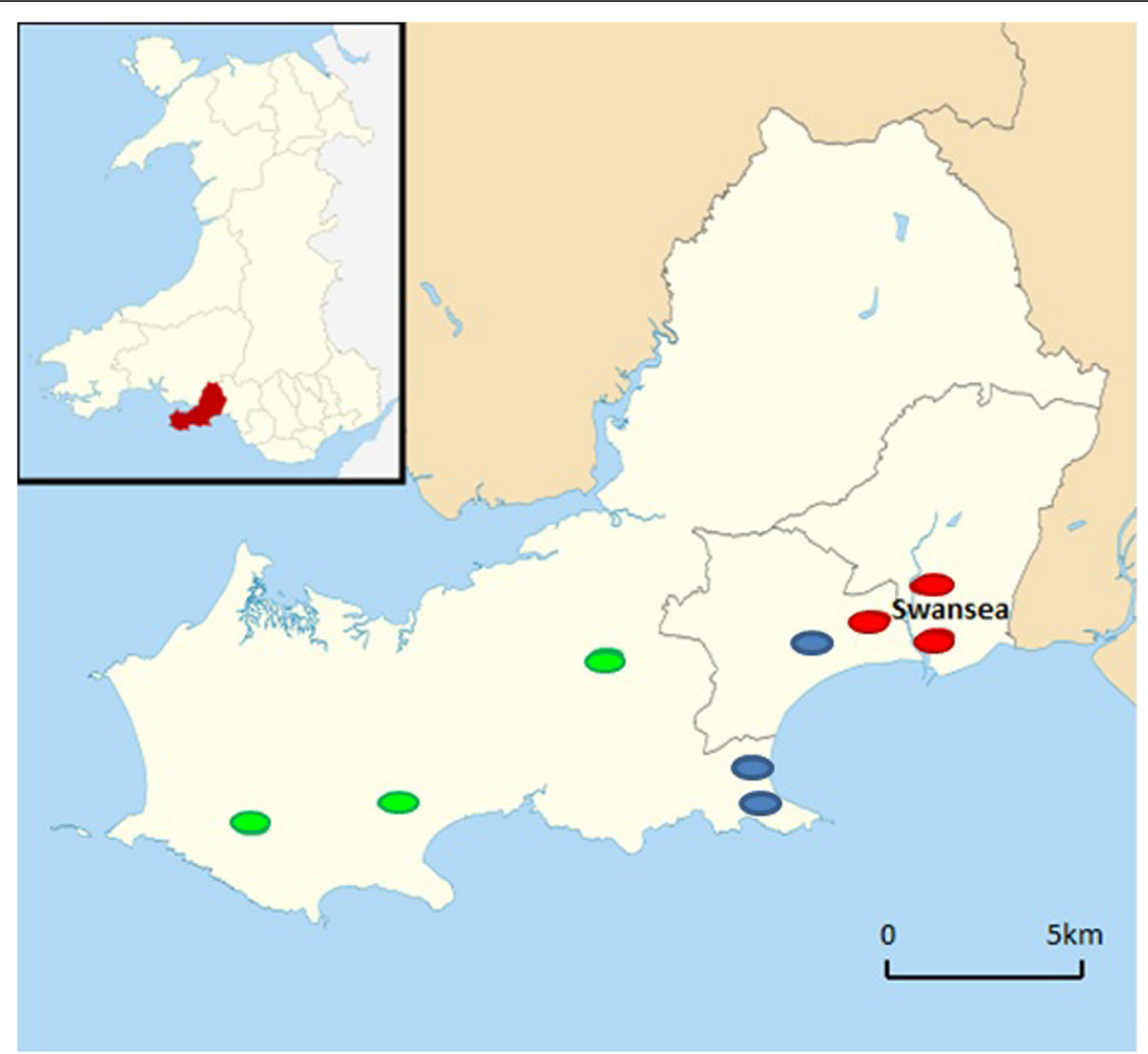

Fig. 1 Map of sampling locations in Swansea. Inset: outline and position within Wales of the City and County of Swansea. Sampling sites are marked as follows: red, urban; blue, suburban; green, rural)

portion of the ITS-2 (internal transcribed spacer 2) gene (180 base pairs) was amplified using the following primers: I2F2 5'-GCGTGTGTTCATGTTTGGAC-3' and I2R2 5'CATTACTAGCATACAAGCACATG-3' [18]. Real-time PCR assays were performed in a final reaction volume of $25 \mu \mathrm{l}$ that consisted of $12.5 \mu \mathrm{l}$ of $2 \times$ Quantifast SYBR Green PCR Master Mix (QIAGEN, Germany), $1 \mu \mathrm{M}$ of each primer and $6.5 \mu \mathrm{l}$ of $\mathrm{dH}_{2} \mathrm{O}$. Cycling conditions involved an initial activation step of $95{ }^{\circ} \mathrm{C}$ for $5 \mathrm{~min}$ followed by 40 cycles of $95{ }^{\circ} \mathrm{C}$ for $10 \mathrm{~s}$ and $62{ }^{\circ} \mathrm{C}$ for $30 \mathrm{~s}$ using a Mx3005P quantitative PCR system (Stratagene, California, USA). For all assays, positive (adult $A$. vasorum DNA) and negative (absence of DNA template) controls were included.

For samples from freshly collected slugs, higher fluorescence on 10-fold dilution of some extractions suggested the possible presence of PCR inhibitors as seen in previous studies [18]. All extractions were diluted 1:10 to surmount this. The cycle number was increased from 40 to 50 following dilution to allow sufficient amplification of PCR product.
In order to check for false negatives arising from localisation of larvae outside the $10 \mathrm{mg}$ foot muscle sample, a total of 58 slugs testing negative by PCR, from all localities of Swansea [suburban $(n=16)$; urban $(n=21)$ and rural $(n=$ $21)]$ were homogenised. The slugs were individually homogenised using a mortar and pestle and $25 \mathrm{mg}$ of tissue randomly taken for DNA extraction and real time PCR analysis.

\section{Statistical analysis}

The prevalence of $A$. vasorum was compared across localities using Chi-square tests, and across slug species using Fisher's exact test, in both cases using global prevalence to calculate expected frequencies. To describe variation in slug species composition in Bristol and Swansea, Principal Components Analysis (PCA) was used, with sample site set as group and slug species as the list of variables (SPSS Statistics version 21, IBM, USA). Chi-square tests were further used to compare the relative frequency of individual slug species in samples from different localities. $P$ values of $<$ 0.05 were considered to be statistically significant. 


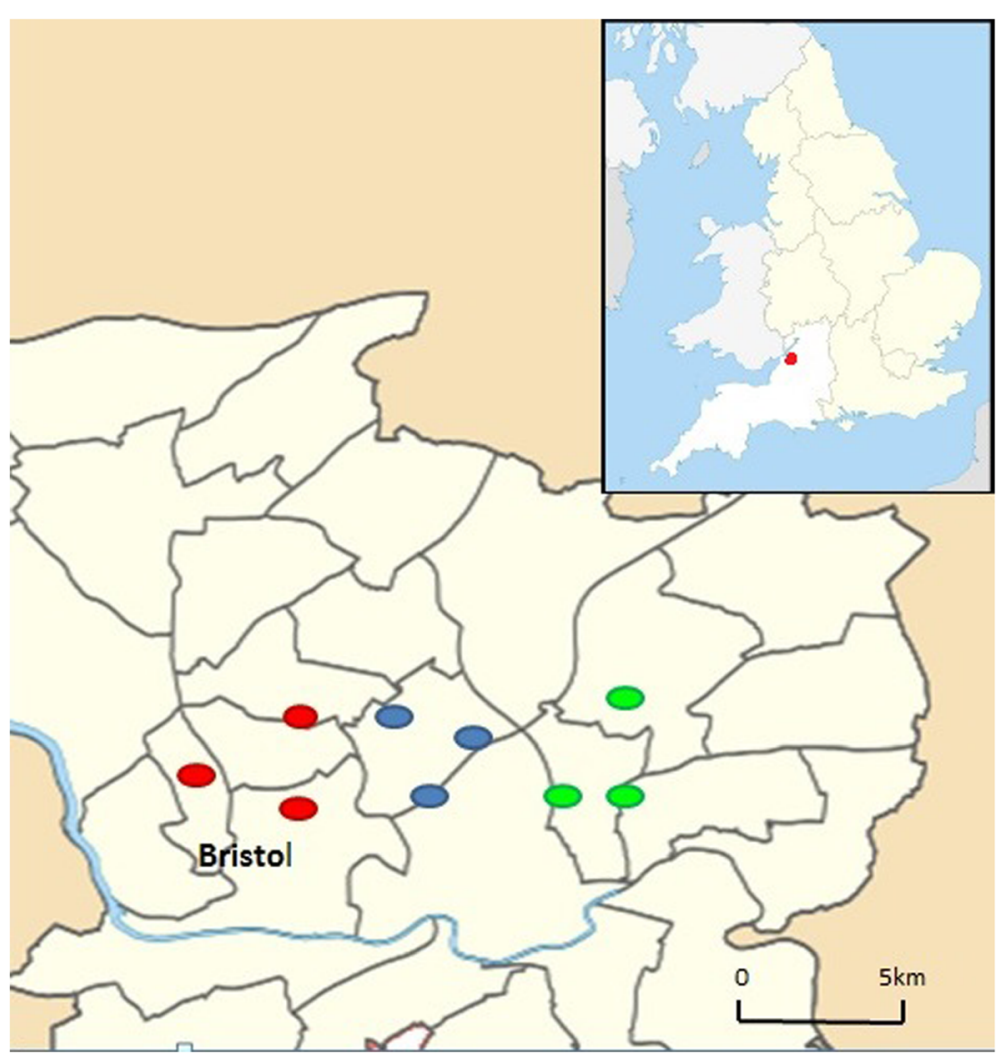

Fig. 2 Map of sampling locations in Bristol (inset: location in UK; lines: electoral ward boundaries). Sampling sites are marked as follows: red, urban; blue, suburban; green, rural)

\section{Results}

\section{Prevalence of Angiostrongylus vasorum in slugs}

In Swansea, of the 180 slugs examined for A. vasorum infection, 53 (29.4\%) were positive by real time PCR assay. More than half of all infected slugs were recorded in suburban environments (Fig. 3). The prevalence of A. vasorum was significantly different between the habitats sampled (urban, suburban and rural; $\chi^{2}=14.78$, d.f. $=2, p<0.001$ ). There was no significant difference in prevalence between suburban and urban habitats $(p=0.15)$; however, infection was significantly more common in suburban than in rural slugs $\left(\chi^{2}=14.16\right.$, d.f. $\left.=1, p<0.001\right)$. There was also substantially higher prevalence in urban areas compared to rural areas $\left(\chi^{2}=14.54\right.$, d.f. $\left.=1, p<0.001\right)$. In Bristol, only one of the 338 slugs tested positive for $A$. vasorum, and this was collected from a suburban location (Table 3), giving a prevalence of $1.3 \%$ for that park and a prevalence of $0.3 \%$ overall for the sites in Bristol. All slugs homogenised $(n=58)$ for identification of false negatives gave a negative result.

Table 1 Locations sampled in Swansea in autumn 2012

\begin{tabular}{lllll}
\hline Site & Abbreviation & Description & Number of slugs & Date of collection \\
\hline Underhill park & UP & Suburban & 20 & $13 . x .2012$ \\
Cwmdonkin park & CP & Suburban & $14 . \times .2012$ \\
West cross & WC & Suburban & $18 . x .2012$ \\
Woodlands terrace & WT & Urban & 20 & $21 . x .2012$ \\
Sainsbury's car park & SC & Urban & 20 & $23 . x .2012$ \\
Landore & L & Urban & 20 & $25 . x .2012$ \\
Penrice & P & Rural & 20 & $29 . x .2012$ \\
GelliHir & GH & Rural & 20 & $30 . x .2012$ \\
Pilton green & PG & Rural & 20 & $01 . x i .2012$ \\
\hline
\end{tabular}


Table 2 Locations sampled in Bristol in summer 2014

\begin{tabular}{lllll}
\hline Site & Abbreviation & Description & Number of slugs & Date of collection \\
\hline St Andrews park & SAP & Urban & 23 & 05. vii.2014 \\
St George park & SGP & Urban & 19 & $10 . v i i .2014$ \\
Oldbury Court Estate & OCE & Urban & 50 & 14. vii.2014 \\
Warmley forest park & RWH & Suburban & 44 & $16 . v i i .2014$ \\
Overscourt wood & WFP & Suburban & 73 & $19 . v i i .2014$ \\
Rodway Hill & OCW & Suburban & 28 & $20 . v i i .2014$ \\
Wapley Bushes nature reserve & WBN & Rural & 47 & $25 . v i i .2014$ \\
Golden Valley nature reserve & GVN & Rural & 26 & $23 . v i i .2014$ \\
Brockwell park & BWP & Rural & 28 & $02 . v i i i .2014$ \\
\hline
\end{tabular}

\section{Comparison of slug species across locations}

Principal components analysis (PCA) revealed differences in the composition of the slug fauna in different locations (Table 4), but no clear overall pattern along the urban-rural gradient or between the two cities (Fig. 4). Using univariate Chi-square tests, however, Ar. rufus was found to be more common in all habitats sampled in Swansea compared with Bristol (Table 5). By contrast, Ar. flagellus was more common at sub-urban and rural habitats in Bristol than in Swansea. Deroceras reticulatum and L. maximus were also more common in Bristol than in Swansea. Arion flagellus was significantly more common at combined suburban and urban than rural habitats in Bristol (Table 6), while Ar. owenii and $T$. sowerbyi were more common in rural locations. In Swansea, L. maculatus was found only in the urban habitats.

\section{Discussion}

These results demonstrate for the first time a ruralurban gradient in $A$. vasorum prevalence in intermediate hosts in the UK. Higher prevalence of A. vasorum in suburban areas is consistent with studies in Denmark in gastropods [19] and in foxes [23]. Peak prevalence in suburban areas could be explained by overlap of high fox population density and high density of suitable intermediate hosts, as proposed for the fox tapeworm, Echinococcus multilocularis, in Europe [24].

Wide variation in the prevalence of A. vasorum at different sites and between the cities of Swansea and Bristol demonstrates a high level of spatial heterogeneity in parasite distribution among intermediate host populations. Previous studies have noted marked geographical patchiness of angiostrongylosis in definitive hosts [25-28]. The reasons for this patchy distribution are unknown [30],

Swansea

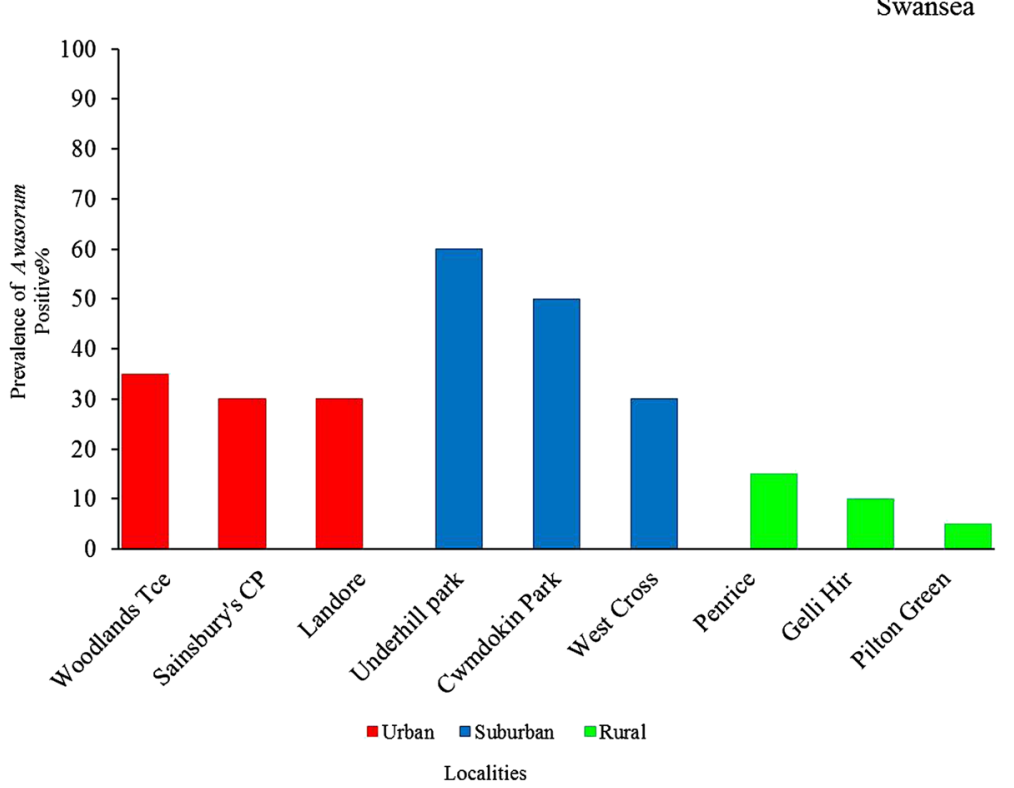

Fig. 3 Prevalence of slugs infected with Angiostrongylus vasorum as determined by real-time PCR, across nine locations spanning the rural-urban gradient in Swansea 
Table 3 Composition of gastropod collections made in Swansea in 2012 and Bristol in 2014, and prevalence of Angiostrongylus vasorum using real-time PCR. $N$ = number of each species collected, and number and percentage positive by PCR

\begin{tabular}{|c|c|c|c|c|c|c|c|c|}
\hline \multicolumn{3}{|l|}{ Gastropod I.D. } & \multicolumn{6}{|c|}{ Location of collection } \\
\hline \multirow[t]{2}{*}{ Family } & \multirow[t]{2}{*}{ Genus } & \multirow[t]{2}{*}{ Species } & \multicolumn{3}{|c|}{ Swansea } & \multicolumn{3}{|c|}{ Bristol } \\
\hline & & & $\bar{N}$ & $N$ positive & $\%$ positive & $\bar{N}$ & $N$ positive & $\%$ positive \\
\hline \multirow[t]{7}{*}{ Arionidae } & Arion & rufus & 68 & 28 & 41 & 27 & 0 & 0 \\
\hline & Arion & flagellus & 27 & 7 & 26 & 115 & 1 & 0.9 \\
\hline & Arion & subfuscus & 1 & 0 & 0 & 5 & 0 & 0 \\
\hline & Arion & distinctus & - & - & - & 3 & 0 & 0 \\
\hline & Arion & owenii & - & - & - & 12 & 0 & 0 \\
\hline & Arion & ater & - & - & - & 16 & 0 & 0 \\
\hline & Arion & fasciatus & - & - & - & 3 & 0 & 0 \\
\hline Agriolimacidae & Deroceras & reticulatum & 3 & 0 & 0 & 93 & 0 & 0 \\
\hline \multirow[t]{2}{*}{ Limacidae } & Limax & maximus & 1 & 0 & 0 & 12 & 0 & 0 \\
\hline & Limacus & maculatus & 18 & 8 & 44 & 30 & 0 & 0 \\
\hline Milacidae & Tandonia & sowerbyi & 4 & 0 & 0 & 22 & 0 & 0 \\
\hline Total & & & 122 & 43 & 35.2 & 338 & 1 & 0.3 \\
\hline
\end{tabular}

and could include spatial variation in intermediate host density and species composition, and in environmental factors influencing transmission, as well as local movement of infected intermediate hosts around new parasite introductions [30-32].

The prevalence of $29.4 \%$ in Swansea in the current study is considerably higher than the $1.6 \%$ recorded by Patel et al. [20] in London, by extraction and identification of larvae from gastropod tissues. Larval extraction methods are likely to underestimate true infection prevalence, through low sensitivity and because pre-infective stage larvae are usually not recovered [Abdul-Aziz, unpublished observations]. Conversely, prevalence estimated from PCR does not accurately reflect the presence of mature larvae able to propagate infection in definitive hosts, since earlier larval stages and, potentially, residual DNA from non-viable larvae can also be detected [11].

Table 4 Component loadings for the first two principal components (PC), used to compare slug species composition between sampled locations. PC1 (eigenvalue 1.68) explained $24 \%$ of the total variance; and PC2 (eigenvalue 1.59) explained $23 \%$ of the total variance

\begin{tabular}{lcc}
\hline Variable (slug species) & Component 1 & Component 2 \\
\hline A. rufus & 0.50 & -0.77 \\
A. flagellus & 0.64 & 0.55 \\
A. ater & 0.45 & 0.01 \\
D. reticulatum & 0.20 & 0.78 \\
L. maximus & -0.10 & -0.23 \\
L. maculatus & -0.85 & 0.17 \\
T. sowerbyi & -0.23 & 0.06 \\
\hline
\end{tabular}

Prevalence estimates using these different methods are, therefore, not comparable. Low prevalence in a large sample size in the present study in Bristol suggests that false positive results are not common using this PCR assay.

In the present study, slug species were identified by external and internal morphology based on Rowson et al. [22], a new comprehensive guide to British and Irish slugs validated by PCR amplification and sequencing of mitochondrial (16S, COI) and nuclear (ITS-1) DNA. Previous work on A. vasorum in slugs [18-20] examined 'aggregates' of superficially similar species. The present study therefore provides more accurate information on species distribution of $A$. vasorum based on more specific identification.

The present study found broadly similar slug species composition in the nearby cities of Swansea and Bristol. Together with the wide host range observed here and in previous studies, this suggests that the overall prevalence of A. vasorum is not closely related to the presence or absence of particular intermediate host species. Nevertheless, some differences in slug fauna were noted. Sampling in Swansea yielded fewer species overall, even allowing for lower sample size, and less variability in slug species between sites compared with Bristol. Arion rufus was relatively more common across locations in Swansea, and Ar. flagellus and some of the smaller slug species were more common in Bristol. Reasons for these differences could include ecological factors (e.g. climate, soil, habitat, or predation) or a history of accidental introduction (perhaps especially for those species found at single sites). However, the consistent differences in abundance of widespread species present at all sites (Ar. rufus and $A r$. 


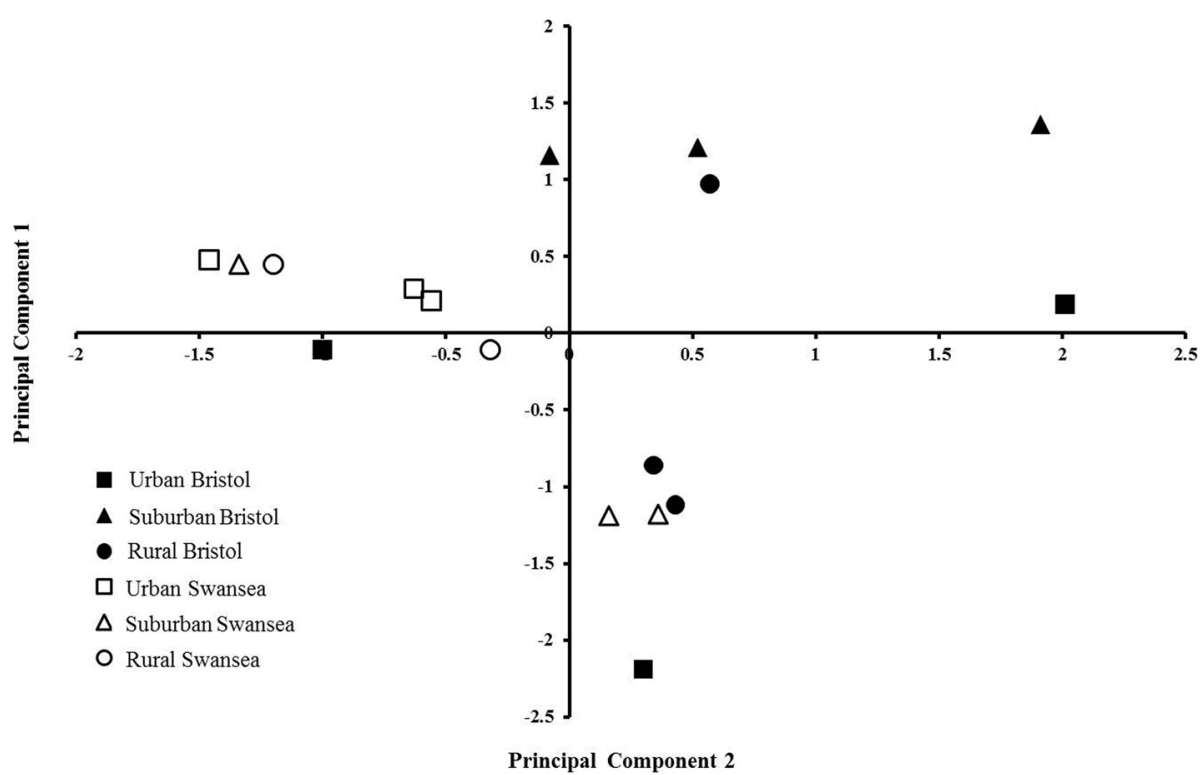

Fig. 4 Ordination of sample location on the first two principal component axes of the Principal Components Analysis (PCA). See Table 4 for component loadings and eigenvalues

flagellus) seem more likely to be due to ecological rather than historical factors. Arion rufus, widely found and commonly infected in the Swansea samples, has been acknowledged to act as an efficient host of $A$. vasorum and to be a major potential source of infection in various locations [18, 33, 34]. It appears that in urban areas of Swansea, L. maculatus acts as additional or secondary host. In Bristol, the lower availability of Ar. rufus as the preferred or optimal host of A. vasorum in Bristol

Table 5 Number of specimens of each slug species collected in Swansea and Bristol

\begin{tabular}{|c|c|c|c|c|c|c|}
\hline \multirow[t]{2}{*}{ Species } & \multicolumn{2}{|l|}{ Urban } & \multicolumn{2}{|l|}{ Suburban } & \multicolumn{2}{|l|}{ Rural } \\
\hline & Swansea & Bristol & Swansea & Bristol & Swansea & Bristol \\
\hline A. rufus & $16^{a}$ & $7^{a}$ & $33^{b}$ & $15^{\mathrm{b}}$ & $19^{c}$ & $5^{c}$ \\
\hline A. flagellus & 5 & 6 & $13^{b}$ & $92^{b}$ & $9^{c}$ & $17^{c}$ \\
\hline A.subfuscus & 1 & 0 & 0 & 4 & 0 & 1 \\
\hline A.distinctus & 0 & 3 & 0 & 0 & 0 & 0 \\
\hline A. owenii & 0 & 12 & 0 & 0 & 0 & 0 \\
\hline A. ater & 0 & 3 & 0 & 8 & 0 & 5 \\
\hline A. fasciatus & 0 & 0 & 0 & 3 & 0 & 0 \\
\hline D. reticulatum & $3^{a}$ & $44^{a}$ & $0^{b}$ & $25^{b}$ & $0^{b}$ & $24^{b}$ \\
\hline L. maximus & $0^{a}$ & $10^{a}$ & 0 & 0 & 1 & 2 \\
\hline L. maculatus & 18 & 21 & 0 & 0 & 0 & 9 \\
\hline T. sowerbyi & 0 & 1 & 0 & 1 & 4 & 20 \\
\hline Total & 43 & 92 & 46 & 148 & 33 & 98 \\
\hline
\end{tabular}

Super-scripts show significant differences $(p<0.05)$ using Chi-square when comparing: ${ }^{a}$ urban localities in Swansea and Bristol; ${ }^{b}$ suburban localities in Swansea and Bristol; ${ }^{c}$ rural localities in Swansea and Bristol might explain the low overall infection prevalence. Nevertheless, Ar. flagellus and L. maculatus were abundant and could be important alternative hosts in such areas.

The broad intermediate host range observed in this study is in agreement with previous data on experimental and natural infections [18-20,35]. Around 25 species have been successfully infected in an experimental

Table 6 Number of specimens of each slug species collected in Swansea and Bristol, pooling urban and suburban environments in each area

\begin{tabular}{llllll}
\hline Species & \multicolumn{3}{l}{ Swansea } & & Bristol \\
\cline { 2 - 3 } \cline { 5 - 6 } & Urban and suburban & Rural & & Urban and suburban & Rural \\
\hline A. rufus & 49 & 19 & 22 & 5 \\
A. flagellus & 18 & 9 & $98^{\mathrm{b}}$ & $17^{\mathrm{b}}$ \\
A. subfuscus & 1 & 0 & 4 & 1 \\
A. distinctus & 0 & 0 & 0 & 3 \\
A. owenii & 0 & 0 & $0^{\mathrm{b}}$ & $12^{\mathrm{b}}$ \\
A. ater & 0 & 0 & 11 & 5 \\
A. fasciatus & 0 & 0 & 3 & 0 \\
D. reticulatum & 3 & 0 & 69 & 24 \\
L. maximus & 0 & 1 & 10 & 2 \\
L. maculatus & $18^{\mathrm{a}}$ & $0^{\mathrm{a}}$ & 21 & 9 \\
T. sowerbyi & 0 & 4 & $2^{\mathrm{b}}$ & $20^{\mathrm{b}}$ \\
Total & 89 & 33 & 240 & 98 \\
\hline Superscipss & & & 24 &
\end{tabular}

Super-scripts show significant differences $(p<0.05)$ using Chi-square when comparing: ${ }^{a}$ (sub-)urban and rural localities in Swansea; ${ }^{\mathrm{b}}$ (sub-)urban and rural localities in Bristol 
setting. These are: (i) terrestrial slugs (Deroceras reticulatum, D. agreste, D. laeve, Arion lusitanicus, Ar. hortensis, Limax flavus, Laevicaulus alte); (ii) terrestrial snails (Arianta arburstorum, Bradybaena similaris, Cochlodina laminata, Cepea nemoralis, Euparypha pisana, Prosopeas javanicum, Helix aspersa, Helix pomatia, Subulina octona, Succinea putris, Achatina fulica,Vitrea diaphana); (iii) aquatic snails (Lymnaea peregra peregra, Lymnaea tomentosa, Planorbis planorbis, Biomphalaria glabrata, Anisus leucostomus, Physa sp.) [33, 35-40]. In natural infections, mollusc species reported to be hosts for A. vasorum were: Arionidae: Arion ater aggregate (including A. ater seg., A. rufus seg., A. lusitanicus auctt.), Arion hortensis aggregate (including $A$. distinctus), Arion subfuscus aggregate (including A. subfuscus seg.), Geomalacus maculatus; Agriolimacidae: Deroceras sp., Deroceras reticulatum, Deroceras caruanae auctt., Deroceras laeve, Limacidae: Limax sp., Limax marginatus, Limax maximus, Limacus maculatus; Milacidae: Milax sp., Tandonia sowerbyi; Snails: Cornu aspersum $[4,11,18-20,33-35,38$, 41]. However, the extent to which these types of mollusc are accessible to definitive hosts may vary. A broad intermediate host range has also been reported for other Angiostrongylus species, such as A. cantonensis [42, 43] and $A$. costaricensis $[44,45]$.

The slugs most commonly infected in this study were larger Arion spp., which have been previously found to have higher larval burdens than smaller slugs [41, 46]. Rosen et al. [38] reported average infection levels in $A r$. rufus of 750 L3 and over 1000 in some cases. Arion flagellus and L. maculatus, alternative hosts for $A$. vasorum in the present study, are also among the larger slug species. It is possible that these larger slugs are more commonly infected than others through greater coprophagic tendencies. Arion flagellus was found to be a new host record for $A$. vasorum. There is evidence of ongoing distributional spread of both Ar. flagellus and L. maculatus in the UK and elsewhere [21, 22].

The current study demonstrated infection of slugs with A. vasorum in summer and autumn, confirming previous records in summer [18], autumn [19] and summer and winter [20]. Thus, slugs are likely to present a source of infection to dogs all year round. The much lower prevalence in Bristol in summer, compared with that in Swansea in autumn, might stem from a seasonal rather than a spatial effect, and results are therefore not comparable between locations. Higher prevalence in autumn might be expected based on accumulation of infection and maturation of larvae through the summer months. More information is needed on seasonal variation in $A$. vasorum prevalence in intermediate hosts, to contribute to better understanding of the seasonal epidemiology and risks of infection to dogs, and also to guide efficient sampling for surveillance or spatial studies.

\section{Conclusions}

In conclusion, the results presented here demonstrate heterogeneity in the distribution of $A$. vasorum infection in slugs in two nearby cities, and variation in prevalence along the rural-urban gradient. The composition of the slug fauna appears to play a role in parasite distribution at these scales. Further studies are needed to account for ecological and host factors underlying species differences in intermediate host infections, and to separate spatial from seasonal drivers of prevalence.

\section{Competing interests}

The authors declare that they have no competing interests.

\section{Authors' contributions}

NA, SA and EM conceived the study and all authors participated in its design. NA, ED, SA, BR, CG and DF planned and undertook slug collections and identification, NA performed the real time PCR assay, and NA and EM conducted the statistical analysis and drafted the manuscript. All authors read and approved the final version of the manuscript.

\section{Acknowledgements}

We are grateful to the Swansea and Cardiff team for assistance with the slug collection and transport of material, and to Dr Andy Bailey at the University of Bristol for the access to laboratory equipment. This work was funded by a $\mathrm{PhD}$ scholarship grant from the Government of Malaysia.

\section{Author details}

${ }^{1}$ University of Bristol, Veterinary Parasitology \& Ecology Group, School of Biological Sciences, Bristol Life Sciences Building, 24, Tyndall Avenue, Bristol BS8 1TQ, UK. ${ }^{2}$ School of Animal Sciences, Faculty of Bioresources and Food Industry, Universiti Sultan Zainal Abidin, Kampus Tembila, 22200 Terengganu, Malaysia. ${ }^{3}$ Department of Biosciences, Swansea University, Singleton Park, Swansea SA2 8PP, UK. ${ }^{4}$ Department of Natural Sciences, National Museum of Wales, Cardiff, Wales CF10 3NP, UK.

Received: 17 November 2015 Accepted: 22 January 2016 Published online: 02 February 2016

\section{References}

1. Conboy G. Natural infections of Crenosoma vulpis and Angiostrongylus vasorum in dogs in Atlantic Canada and their treatment with milbemycin oxime. Vet Rec. 2004;115:16-8.

2. Traversa D, Cesare AD, Conboy G. Canine and feline cardiopulmonary parasitic nematodes in Europe: emerging and underestimated. Parasites Vectors. 2010;3:62

3. Jacob DE, Prole JHB. Angiostrongylus vasorum and other nematodes in British Greyhounds. Vet Rec. 1975;96:180.

4. Simpson VR, Neal C. Angiostrongylus vasorum infection in dogs and slugs. Vet Rec. 1982;111:303-4.

5. Patteson WM, Wotton PR, Lucke VM, Wright Al, Gibbs C. Angiostrongylus vasorum in a Terrier. Vet Rec. 1987;120:349.

6. Trees AJ. Angiostrongylus vasorum in dogs in Wales. Vet Rec. 1987;120:424.

7. Chapman P, Boag AK, Guitan J, Boswood A. Angiostrongylus vasorum infection in 23 dogs (1999-2002). J Small Anim Pract. 2004;45:435-40.

8. Philbey AW, Delgado D. Detection of Angiostrongylus vasorum in red foxes in Scotland. Vet Rec. 2013;173:148.

9. Yamakawa Y, McGarry JW, Denk D, Dukes-McEwan J, McDonald N, Mas A, et al. Emerging canine angiostrongylosis in northern England: five fatal cases. Vet Rec. 2009:164:149-52.

10. Helm J, Gilleard JS, Jackson M, Redman E, Bell R. A case of canine Angiostrongylus vasorum in Scotland confirmed by PCR and sequence analysis. J Small Anim Pract. 2009:50:255-9.

11. Helm J, Roberts L, Jefferies R, Shaw SE, Morgan ER. Epidemiological survey of Angiostrongylus vasorum in dogs and slugs around a new endemic focus in Scotland. Vet Rec. 2015; doi: 10.1136/vr.103006.

12. Taylor CS, Gato RG, Learmount J, Aziz NA, Montgomery C, Rose H, et al. Increased prevalence and geographic spread of the cardiopulmonary 
nematode Angiostrongylus vasorum in fox populations in Great Britain. Parasitology. 2015;142:1190-5.

13. Kirk L, Limon G, Guitan FJ, Hermosilla C, Fox MT. Angiostrongylus vasorum in Great Britain: a nationwide postal questionnaire survey of veterinary practices. Vet Rec. 2014;175:118.

14. Helm JR, Morgan ER, Jackson MW, Wotton P, Bell R. Canine angiostrongylosis: an emerging disease in Europe. J Vet Emerg Crit Care. 2010;20(1):98-109.

15. Kutz SJ, Hoberg EP, Nishi J, Polley L. Development of the muskox lungworm, Umingmakstrongylus pallikuukensis (Protostrongylidae), in gastropods in the Arctic. Can J Zool. 2002;80:1977-85.

16. Jenkin EJ, Kutz SJ, Hoberg EP, Polley L. Bionomics of larvae of Parelaphostrongylus odocoilei (Nematoda: Protostrongylidae) in experimentally infected gastropod intermediate hosts. J Parasitol. 2006;92(2):298-305.

17. Bolt G, Monrad J, Koch J, Jensen AL. Canine angiostrongylosis: a review. Vet Rec. 1994:135(19):447-52

18. Jefferies R, Morgan ER, Shaw SE. A SYBR-green real-time PCR assay for the detection of the nematode Angiostrongylus vasorum in the definitive and intermediate hosts. Vet Parasitol. 2009;166(1-2):112-8.

19. Ferdushy $T$, Kapel CMO, Webster P, Al-Sabi MNS, Gronvold J. The occurrence of Angiostrongylus vasorum in terrestrial slugs from forests and parks in the Copenhagen area. Denmark J Helminthol. 2009;83:379-83.

20. Patel Z, Christina AG, Fox MT, Hermosilla C, Backeljau T, Breugelmans K et al. Molecular identification of novel intermediate host species of Angiostrongy/us vasorum in Greater London. Parasitol Res. 2014;doi 10.1007/s00436-014-4111-6.

21. Rowson B, Anderson R, Turner JA, Symondson B. Slugs of Britain and Ireland: identification, understanding and control. 1st ed. Stafford: FSC Publications; 2014

22. Rowson B, Anderson R, Turner JA, Symondson WOC. The slugs of Britain and Ireland: undetected and undescribed species increase a well-studied, economically important fauna by more than $20 \%$. PLoS One. 2014;9(3), e91907.

23. Saeed I, Maddox-Hyttel C, Monrad J, Kapel CMO. Helminths of red foxes (Vulpesvulpes) in Denmark. Vet Parasitol. 2006;139:168-79.

24. Deplazes P, Hegglin D, Gloor S, Romig T. Wilderness in the city: the urbanization of Echinococcus multilocularis. Trends Parasitol. 2004;20:77-84.

25. Morgan ER, Shaw SE, Brennan SF, De Waal TD, Jones BR, Mulcahy G. Angiostrongylus vasorum: a real heartbreaker. Trends Parasitol. 2005;21:49-51.

26. Koch J, Willesen JL. Canine pulmonary angiostrongylosis: an update. Vet J. 2009;79:348-59.

27. Conboy GA. Canine angiostrongylosis: the French heartworm: an emerging threat in North America. Vet Parasitol. 2011;176:382-9.

28. Blehaut TRW, Hardstaff JL, Chapman PS, Pfeiffer DU, Boag AKF, Guitian J. Spatial, demographic and clinical patterns of Angiostrongylus vasorum infection in the dog population of Southern England. Vet Rec. 2014; doi: 10.1136/vr.102186.

29. Morgan ER. Canine pulmonary angiostrongylosis: can a worm change its spots? Vet Rec. 2014;175:116-7.

30. Lahodny GEJ, Allen LJS. Probability of a disease outbreak in stochastic multipatch epidemic models. Bull Mathematical Biol. 2013;75(7):1157-80.

31. Grimm B, Paill W. Spatial distribution and home-range of the pest slug Arion lusitanicus. Acta Oecologia. 2001;22:219.

32. Morgan ER, Milner-Gulland EJ, Torgerson PR, Medley GF. Ruminating on complexity: macroparasites of wildlife and livestock. Trends Ecol Evol. 2004; 19(4):181-8.

33. Eckert J, Lammler G. Angiostrongylose bei Mensch Und Tier. Zeitschrift fur Parasitenkunde. 1972;39:303-22.

34. Tonsberg H. Danske landsmegles epidemiologiske betydning for Angiostrongylus vasorum livscyklus (praeliminaere observationer vedr etableringen af A. vasorum in danske landsnegle pa sjaelland juni/juli 2004). Microbiologisk Projekt. 2004.

35. Guilhon J, Cens B. Angiostrongylus vasorum (Baillet, 1866) etude biologique et morphologique. Annales de Parastiologie Humaine et Comparee. 1973:48:567-96

36. Guilhon J. Larval development of A. vasorum (Baillet 1866) in the Arionidae organism. Comptes Rendus de I'Academie des Sciences. 1965;261:4225-7.

37. Guilhon J, Afghahi A. Evolution larvaire d'Angiostrongylus vasorum (Baillet, 1866) dans l' organisme de diverse especes de mollusques terrestres. Comptes rendus de l'Acadamie des Sciences, Paris. 1969;268:434-6.
38. Rosen L, Lawrence R, Wallace GD. Life history of the canine lungworm Angiostrongylus vasorum (Baillet). Am J Vet Res. 1970;31(1):131-43.

39. Saurlander R, Eckert J. Die Achatschneck (Achantina fulica) als experimenteller zwischenwirt fur Angiostrongylus vasorum (Nematoda). Zeitschrift fur Parasitenkunde. 1974;44:59-72

40. Barcante TA, Barcante JMP, Costa-Dias SR, Lima WS. Angiostrongylus vasorum (Baillet, 1866) Kamensky, 1905: Emergence of third-stage larvae from infected Biomphalaria glabrata snails. Parasitol Res. 2003;91:471-5.

41. Tonsberg $\mathrm{H}$. Epidemiological study of snail intermediate hosts in the life cycle of Angiostrongylus vasorum in Denmark, MSc Thesis, Department of Small Animal Clinical Sciences, KVL. 2006.

42. Wallace GD, Rosen L. Studies on eosinophillic meningitis V. Molluscan hosts of Angiostrongylus cantonensis on Pacific Islands. Am J Trop Med Hygie. 1969;18:206-16.

43. Yousif F, Lammer $\mathrm{G}$. The suitability of several aquatic snails as intermediate hosts for Angiostrongylus cantonensis. Zeitschriftfür Parasitenkunde. 1975;47:203-10.

44. Rambo PR, Agostini AA, Graeff-Teixeira C. Abdominal angiostrongylosis in Southern Brazil prevalence and parasitic burden in mollusc intermediate hosts from eighteen endemic foci. Memorias do Instituto Oswaldo Cruz, Rio de Jeneiro. 1997;92:9-14.

45. Laitano AC, Genro JP, Fontoura R, Branco S, Siqueira L, Maurer RL, et al. Report on the occurrence of Angiostrongylus costaricensis in southern Brazil, in a new intermediate host from the genus Sarasinula Veronicellidae, Gastropoda). Revista da Sociedade Brasileira de Medicina Tropical. 2001;34:95-7.

46. Ferdushy T, Kapel CMO, Webster P, Al-Sabi MNS, Gronvold JR. The effect of temperature and host age on the infectivity and development of Angiostrongylus vasorum in the slug Arion lusitanicus. Parasitol Res. 2010;doi 10.1007/s00436-010-1850-x

\section{Submit your next manuscript to BioMed Central and we will help you at every step:}

- We accept pre-submission inquiries

- Our selector tool helps you to find the most relevant journal

- We provide round the clock customer support

- Convenient online submission

- Thorough peer review

- Inclusion in PubMed and all major indexing services

- Maximum visibility for your research

Submit your manuscript at www.biomedcentral.com/submit
) Biomed Central 